\title{
Quantification of Mesophyll Resistance and Apoplastic Ascorbic Acid as an Antioxidant for Tropospheric Ozone in Durum Wheat (Triticum durum Desf. cv. Camacho)
}

\author{
Daniel de la Torre \\ Universidad Politécnica de Madrid, Plant Biology Department, ETSI Agrónomos, \\ 28040 Madrid \\ E-mail: daniel.delatorre@upm.es
}

Received July 7, 2008; Revised October 23, 2008; Accepted November 6, 2008; Published December 14, 2008

\begin{abstract}
The daily variations in cellular and apoplastic ascorbic acid and dehydroascorbic acid levels in a Mediterranean durum wheat cultivar (Triticum durum Desf. cv. Camacho) were analyzed in order to relate them to ambient ozone exposure and to subsequent stomatally absorbed ozone fluxes. The aim of this study is to prove the effectiveness and accuracy of a computer model (SODA) to calculate the mesophyll resistance $\left(r_{m}\right)$ to ozone uptake, the percentage of ozone detoxification by apoplastic ascorbic acid, and the ozone flux to the plasmalemma $\left(F_{m}\right)$ in a Mediterranean durum wheat cultivar. These calculated factors were related to apoplastic ascorbic acid levels and to ambient ozone concentrations. These relationships were obtained with a view to explaining the detoxification of ozone by apoplastic ascorbic acid. Ozone detoxifications of up to $52 \%$ were found at midday, when maximum ozone concentrations and maximum apoplastic ascorbic acid are seen. Mesophyll resistance was minimum at this time, and ozone flux to the plasmalemma was reduced because of the reaction of ozone with apoplastic ascorbic acid.
\end{abstract}

KEYWORDS: apoplastic ascorbic acid, detoxification, mesophyll resistance, ozone, SODA, Triticum durum

\section{INTRODUCTION}

Scientific evidence has revealed that tropospheric ozone is a highly phytotoxic pollutant and that it is able to cause a decrease in cultivar yields, alter the composition and diversity of some ecosystems, and contribute to a decrease in forest vitality[4,6,9,14,15].

Current ozone toxicity thresholds are based on exposure to the pollutant and the biological response parameters[40]. Nevertheless, the response of the vegetation to atmospheric pollution is strongly dependent on the amount of pollutant that enters the leaf and the resistance of the plants themselves[7,12,13,16,32,38,41]. By means of resistance models, currently intense efforts are being made to characterize ozone deposition in order to establish new ozone threshold values based on ozone uptake fluxes[8,10,41]. 
The main entry of ozone into plants is through the stomata[19,36] and, hence, stomatal resistance $\left(\mathrm{r}_{\mathrm{s}}\right)$ is one of the most important factors for ozone absorption and, in turn, for injury to plants. Once ozone has entered the substomatal cavity, it contacts the extracellular environment, undergoing dilution and reaction processes that constitute the last line of defense to the entrance of ozone and its reaction products into the inside of the cell. These processes determine mesophyll resistance $\left(\mathrm{r}_{\mathrm{m}}\right)$.

The ozone in the extracellular environment reacts with water and with cellular components to generate free radicals and active forms of oxygen[27,31]. Once formed, these react with multiple organic compounds and oxidize them, depending on their sensitivity and accessibility, resulting in the first injuries that occur at cellular scale[17,18]. In the extracellular (apoplastic) space, some compounds perform a protective-antioxidant function, in particular ascorbic acid[2,24,33]. Ascorbic acid ( $\mathrm{C}$ vitamin) is a normal constituent of the cells of plants and animals whose main function is to act as an antioxidant. Several authors have described the presence of ascorbic acid in the apoplast, representing about $1 \%$ of total cellular ascorbate[2,25,26]. Apoplastic ascorbic acid (ascorbate) is oxidized to dehydroascorbic acid (dehydroascorbate), but the enzymes required for its retransformation into ascorbate are not present in the apoplast, and ascorbate must be transported into the interior of cells[2,21,24]. Cytosolic dehydroascorbate reductase (DHAR) is a key component of this ascorbate recycling system, as reported for Arabidopsis thaliana (L.) Heynh[43].

The inverse relationship that has been found in many species between cellular ascorbate and the ozone sensitivity of plants highlights the importance of ascorbate as one of the first lines of defense against ozone[2,6,43,45]. In particular, the small proportion of ascorbate present in the apoplast could be sufficiently large to provide a significant defense against ozone[25,26,28,39]. Additionally, the oxidative stress caused by ozone seems to stimulate the conversion of dehydroascorbate to ascorbate[23,43] and the transport of ascorbate from the symplasm to the apoplast[30,35,43]. Owing to the importance of ascorbate as an antioxidant agent against ozone, it could be considered one of the main elements that would determine mesophyll resistance to ozone deposition in plants.

Some authors have considered that mesophyll resistance is negligible in comparison with stomatal resistance[11]. Nevertheless, the importance of mesophyll resistance relies on the fact that it is the cell's last line of defense before a pollutant is able to gain entry to the inside of the cell. In view of the scarce information available about the reactions that occur in the apoplast, the quantification of mesophyll resistance is hugely complicated. One of the few approaches developed for such purposes is the SODA

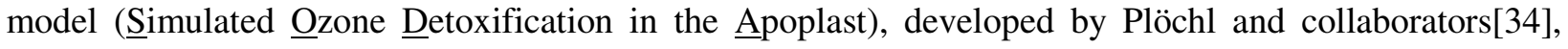
which was used in this study to estimate mesophyll resistance and the detoxifying role of ascorbate in the apoplast.

\section{MATERIALS AND METHODS}

The experiment was conducted at "El Encín" (40³1' N 3²2’ W, Alcalá de Henares, Madrid, Spain), an agricultural area belonging to IMIDRA (Institute of Agricultural Research of Madrid). Two plots of durum wheat (Triticum durum Desf. cv. Camacho), $5 \times 5 \mathrm{~m}^{2}$, were employed and the usual Mediterranean agricultural practices were followed. The Camacho commercial variety was chosen because, based on a preliminary study (data not shown), it is considered as being quite sensitive to ozone. The study was performed during 2 weeks (May 12-23) when the plants were at the phenological stage of anthesis. During this time, the daily profiles of ambient ozone concentrations, the gas exchange rate (stomatal conductance) of the plants, the apoplastic and whole leaf ascorbic acid contents, apoplastic $\mathrm{pH}$, and certain anatomical parameters were analyzed. All measurements were taken from central flag leaf fragments. Quantification of mesophyll resistance $\left(r_{m}\right)$, the percentage of ozone reacting with apoplastic ascorbate and the ozone flux to the plasmalemma, was accomplished using the SODA model[34]. 


\section{Ambient Ozone Concentrations}

Ambient ozone concentrations were recorded using an ultraviolet-photometry ozone analyzer (Dasibi Env. Corp. Model 1003-RS; Glendale, CA). The analyzer was located in a meteorological tower in a wheat field. The air intake was $2.5 \mathrm{~m}$ above the ground and the ozone data were registered continuously and automatically every $10 \mathrm{~min}$ and stored on a data logger (Geonica Meteodata 1256C; Madrid, Spain).

\section{Stomatal Conductance $\left(g_{s}\right)$ Measurements}

Stomatal conductance to water vapor $\left(\mathrm{g}_{\mathrm{s}}, \mathrm{mol} \mathrm{H}_{2} \mathrm{O} \mathrm{m} \mathrm{m}^{-2}\right)$ measurements were made with a portable LiCor 6400 gas exchange analyzer (Li-Cor; Lincoln, NE) over two 24-h cycles (one for each week of the measurements), measuring randomly in flag leaves and avoiding the border effect. Between four to 15 samples per hour were taken, depending on the time availability.

\section{Biochemical Analyses}

A total of 24 samples (i.e., corresponding to 1 day) were taken over 1 week, followed by the same protocol over the next week (replicate samples) for the determination of apoplastic ascorbate, whole leaf ascorbate, and apoplastic pH. Six to eight samples per hour were taken for ascorbate determinations. For apoplastic $\mathrm{pH}$ determinations, eight to 10 samples per hour were taken to obtain a single hourly value.

The efficiency of the method used to obtain apoplastic fluid was analyzed based on the presence of glucose-6-phosphate-dehydrogenase (G6PDH). This enzyme is only found inside cells and, hence, its activity in apoplastic fluid would indicate a contamination of the latter by cytoplasmic fluid. G6PDH activity was analyzed at four moments of the daily cycle: morning, midday, evening, and night.

\section{Preparation of Cellular Extracts}

Extraction was accomplished following the protocol of Takahama and Oniki[37]. Central fragments of flag leaf (2-3 cm long) were used for ascorbate determinations; for this, they were weighed (Cobos precision balance; Madrid, Spain) and homogenized in $1 \mathrm{~mL}$ of ice-cold extraction buffer (metaphosphoric acid, $6 \% \mathrm{p} / \mathrm{v}, 4^{\circ} \mathrm{C}$; Sigma-Aldrich; Madrid, Spain) using a microdismembrator (B-Braun mikrodismembrator-II; AG; Melsungen, Germany). The homogenate was then transferred to Eppendorf tubes $(2.5 \mathrm{~mL})$ and centrifuged (Jouan MR 1812 centrifuge; Saint Nazaire, France) for $4 \mathrm{~min}$ at 10,000 $\mathrm{g}$ and $4^{\circ} \mathrm{C}$. The supernatant was decanted into fresh Eppendorf tubes and the ascorbate content was analyzed immediately.

For cellular G6PDH activity determinations, extracts were processed in the same way, but in this case using $1.5 \mathrm{~mL}$ of buffer $\left(66 \mathrm{~m} M \mathrm{~K}_{2} \mathrm{HPO}_{4} / \mathrm{KHPO}_{4}, 1 \mathrm{~m} M\right.$ EDTA, $10 \mathrm{~m} M \mathrm{MgCl}_{2}$, and $14 \mathrm{~m} M$ DTT; pH 7.6; Sigma-Aldrich; Madrid, Spain). Enzymatic activity was analyzed immediately after the extraction process.

\section{Extraction of Apoplastic Fluid}

The extraction of apoplastic fluid was carried out following the protocol of Takahama and Oniki[37]. Flag leaf fragments $(8-10 \mathrm{~cm}$ long) were weighed, washed with distilled water, and vacuum-infiltrated at -80 $\mathrm{kPa}$ (five periods each of $30 \mathrm{~s})$ with cold $\left(4^{\circ} \mathrm{C}\right)$ buffer $(\mathrm{pH} 3.2)$ containing $66 \mathrm{mM} \mathrm{K \textrm {KH } _ { 2 } \mathrm { PO } _ { 4 } ( \text { Sigma- }}$ Aldrich; Madrid, Spain), $100 \mathrm{~m} M \mathrm{KCl}$ (Sigma-Aldrich; Madrid, Spain), and $2.5 \mathrm{~m} M$ EDTA (Sigma- 
Aldrich; Madrid, Spain). Each leaf was carefully blotted with filter paper until dry, weighed again, and then rolled and inserted into a syringe $(10 \times 1.5 \mathrm{~cm})$. Apoplastic washing fluid was collected in Eppendorf tubes containing $100 \mu \mathrm{L}$ of cold metaphosphoric acid $\left(2 \% \mathrm{p} / \mathrm{v}, 4^{\circ} \mathrm{C}\right.$; Sigma-Aldrich; Madrid, Spain) under centrifugation $(6 \mathrm{~min}$ at $900 \mathrm{~g}$ ). Subsequently, leaf fragments were collected and weighed for a third time. The amount of apoplastic fluid was obtained by weight difference. The amount of ascorbate was analyzed immediately.

For the analysis of G6PDH activity in apoplastic fluid, the infiltrations were performed following a similar protocol, but using a different buffer $\left(66 \mathrm{~m} M \mathrm{~K}_{2} \mathrm{HPO}_{4} / \mathrm{KHPO}_{4}, 1 \mathrm{~m} M\right.$ EDTA, $100 \mathrm{~m} M \mathrm{KCl}, 10$ $\mathrm{m} M \mathrm{MgCl}_{2}$, and 14mM DTT; pH 7.6; Sigma-Aldrich; Madrid, Spain). Then, the leaf fragments were collected, blotted with filter paper, inserted into a syringe $(10 \times 1.5 \mathrm{~cm})$, and centrifuged $(6 \mathrm{~min}$ at $900 \mathrm{~g}$, $\left.4^{\circ} \mathrm{C}\right)$. The apoplastic washing fluid was collected in empty Eppendorf tubes and G6PDH activity was analyzed immediately.

Apoplastic fluid was extracted to assess its $\mathrm{pH}$. Eight to 10 central flag leaf fragments $(8-10 \mathrm{~cm})$ were cut in half perpendicular to leaf length to increase the fluid exit surface. Infiltration was performed with

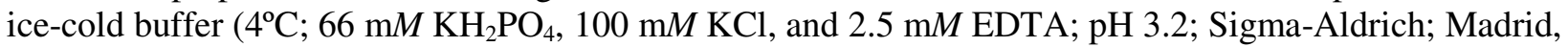
Spain), collecting the apoplastic washing fluid $(<50 \mu \mathrm{L})$ in empty Eppendorf tubes under centrifugation $\left(4^{\circ} \mathrm{C}, 5 \mathrm{~min}\right.$ at $\left.900 \mathrm{~g}\right)$. The $\mathrm{pH}$ of the apoplastic washing fluid was assessed immediately with a microelectrode (6 $\mathrm{mm} \varnothing)$ fitted to a $\mathrm{pH}$ meter (Crison micropH 2001; Madrid, Spain) at $25^{\circ} \mathrm{C}[44]$.

\section{G6PDH Activity Determinations}

G6PDH activity was assessed following the reduction of NADP to NADPH at $340 \mathrm{~nm}$ under spectrophotometry (Perkin Elmer UV/VIS Lambda 2; Wellesley, MA)[22]. The extinction coefficient used for NADPH was $6.22 \mathrm{mM} M^{-1} \mathrm{~cm}^{-1}$. Absorbance was assessed at $25^{\circ} \mathrm{C}$ using calibrated quartz cuvettes $(1 \mathrm{~mL})$ containing $50 \mu \mathrm{L}$ of sample in buffer $\left(66 \mathrm{~m} M \mathrm{~K}_{2} \mathrm{HPO}_{4} / \mathrm{KHPO}_{4}[\mathrm{pH} 7.6], 10 \mathrm{~m} M \mathrm{MgCl}_{2}, 300 \mu M\right.$ NADP, and $2 \mathrm{~m} M$ G6P to start the reaction; Sigma-Aldrich; Madrid, Spain) up to a final volume of $1 \mathrm{~mL}$. Enzyme activity was assessed as the increase in absorbance at $340 \mathrm{~nm}$ since under the above conditions, NADP continued to be transformed into NADPH. Finally, the percentage of apoplastic contamination by cytoplasmic fluid was determined as follows: [(apoplastic G6PDH activity)/(cytoplasmic G6PDH activity) $] \times 100$.

\section{Ascorbate Determinations}

The assessment of apoplastic and symplastic ascorbate and dehydroascorbate levels was carried out by spectrophotometry (Perkin Elmer UV/VIS Lambda 2; Wellesley, MA) following the protocol of Takahama and Oniki[37]. All assays were performed at $25^{\circ} \mathrm{C}$ using calibrated quartz cuvettes $(1 \mathrm{~mL})$ containing $50 \mu \mathrm{L}$ of sample in buffer $\left(1 \mathrm{M} \mathrm{K}_{2} \mathrm{HPO}_{4} / \mathrm{KHPO}_{4}\right.$, $\mathrm{pH} 6.1$, Sigma-Aldrich; Madrid, Spain) up to a final volume of $1 \mathrm{~mL}$. The amount of ascorbate was determined by applying the Lambert-Beer law, at $265 \mathrm{~nm}$, using an extinction coefficient of $14.3 \mathrm{mM}^{-1} \mathrm{~cm}^{-1}$ :

$$
\mathrm{A}=\varepsilon \mathrm{bc} \quad(\text { Eq. } 1)
$$

where $\mathrm{A}$ is absorbance at a fixed wavelength, $\varepsilon$ is the extinction coefficient $\left(M^{-1} \mathrm{~cm}^{-1}\right)$ at the above wavelength $(265 \mathrm{~nm}), \mathrm{b}$ is the light-beam path length through the sample $(\mathrm{cm})$, and $\mathrm{c}$ is the sample concentration $(M)$.

Two replicates were assessed for each sample: $5 \mu \mathrm{L}$ of ascorbate-oxidase (250 U per $250 \mu \mathrm{L}$ of buffer; Sigma-Aldrich; Madrid, Spain) was added to one of the replicates in order to elicit the oxidation of ascorbate to dehydroascorbate; $5 \mu \mathrm{L}$ of dithiotreitol (DTT: $16 \mathrm{mg}$ per $250 \mu \mathrm{L}$ of buffer; Sigma-Aldrich; 
Madrid, Spain) was added to the second replicate in order to induce the reduction of dehydroascorbate to ascorbate. After 2 min of incubation, a second absorbance reading was taken for each replicate. Ascorbate and dehydroascorbate contents were determined from the differences between the two readings. The ascorbate redox status was assessed as: $[\mathrm{AA} /(\mathrm{AA}+\mathrm{DHA})] \times 100$.

\section{Mesophyll Resistance Calculations}

Mesophyll resistance $\left(\mathrm{r}_{\mathrm{m}}\right)$ was calculated using the SODA model[34]. This model further expands the method proposed by Chameides[3] for the estimation of ozone flux to the plasmalemma since it considers the role played by apoplastic ascorbate as the first detoxification system of the cell against ozone. The model calculates the ozone flux that enters the leaf through the stomata and that will react with apoplastic ascorbate, and it is based on current knowledge of the parameters characterizing the ozone-ascorbate reaction. Apoplastic ascorbate was determined from the total cellular ascorbate content (AA + DHA), considering that the distribution of ascorbate and dehydroascorbate in the various subcellular compartments, the rate of ascorbate transport to the apoplast, and leaf geometry and ultrastructure do, in fact, affect the distribution of ozone and ascorbate in the cell. As well as mesophyll resistance, the model also estimates the percentage of ozone reacting with apoplastic ascorbate and the ozone flux to the plasmalemma.

The model requires certain standardized input parameters (Table 1) and some changeable input data (mean hourly values):

- Total leaf ascorbate concentration (AA + DHA, mM)

- Apoplastic $\mathrm{pH}$

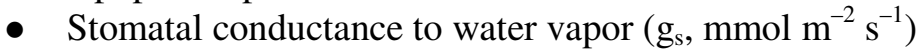

- Ozone concentration at canopy height ( $\mathrm{ppb})$

For each group of input data, the model provides the following output parameters:

- Mesophyll resistance to the entry of ozone into the cell $\left(\mathrm{r}_{\mathrm{m}}, \mathrm{s} \mathrm{m}^{-1} ;\right.$ Fig. 1)

- Ozone flux to the plasmalemma $\left(\mathrm{F}_{\mathrm{m}}, \mathrm{nmol} \mathrm{m}^{-2} \mathrm{~s}^{-1}\right.$; Fig. 2)

- Percentage of ozone reacting with apoplastic ascorbate $\left(\% \mathrm{O}_{3}\right.$ reacted; Fig. 3)

TABLE 1

Standardized Input Values Employed

\begin{tabular}{lcc}
\hline Input & Value & Reference \\
\hline Cell wall thickness & $0.396 \mu \mathrm{m}$ & Experimental \\
Mesophyll cell surface area & $3.4 \mathrm{~m}^{2} \mathrm{~m}^{-2}$ & Experimental \\
Chloroplast volume & $0.0022 \mathrm{~L} \mathrm{~m}^{-2}$ & Experimental \\
Cell wall tortuosity factor & 0.3 & Nobel[29] \\
$\mathrm{O}_{3}$-ASC reaction rate constant & $4.8 \times 10^{7} \mathrm{M}^{-1} \mathrm{~s}^{-1}$ & Kanofsky and Sima[20] \\
$\mathrm{ASC}^{\mathrm{O}} \mathrm{O}_{3}$ reaction stoichiometry & $2: 1$ & Van der Vliet et al.[42] \\
Temperature & $25^{\circ} \mathrm{C}$ & - \\
\hline
\end{tabular}

\section{Statistical Analysis}

The main parameters were studied with regression analysis (Statistica 7.0, StatSoft, Inc., 1996). 


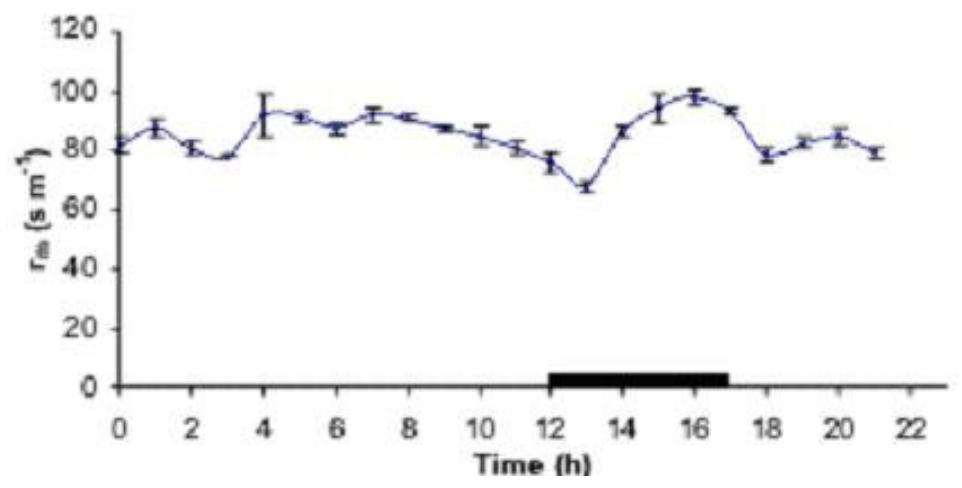

FIGURE 1. Mesophyll resistance $\left(\mathrm{r}_{\mathrm{m}}\right), 24$-h profile. Vertical bars indicate $\pm \mathrm{SE}$. Horizontal thick bar indicates the period of maximum values of ozone. Time is set from 0 to 23 h. $n=24$.

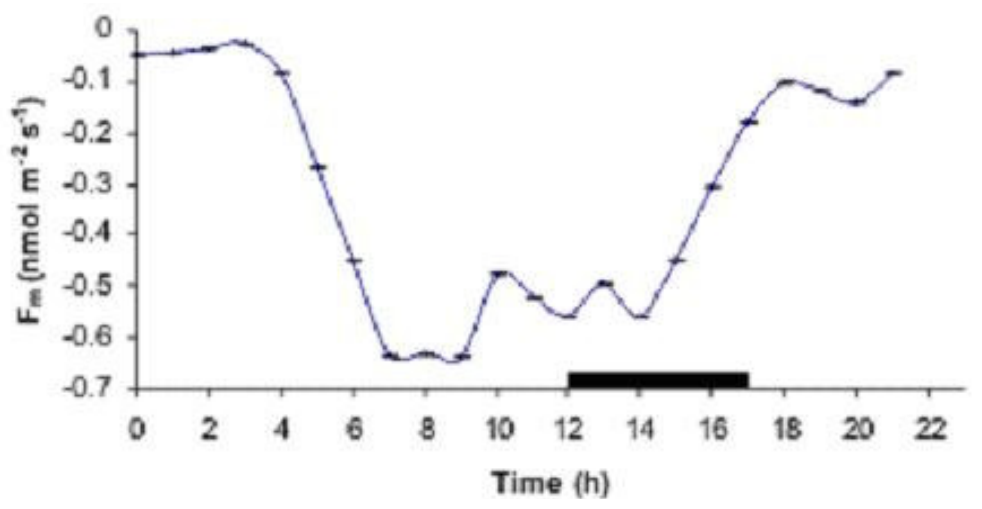

FIGURE 2. Ozone flux to the plasmalemma $\left(F_{m}\right), 24-h$ profile. Vertical bars indicate \pm SE. Horizontal thick bar indicates the period of maximum values of ozone. Time is set from 0 to $23 \mathrm{~h}$. $\mathrm{n}=24$.

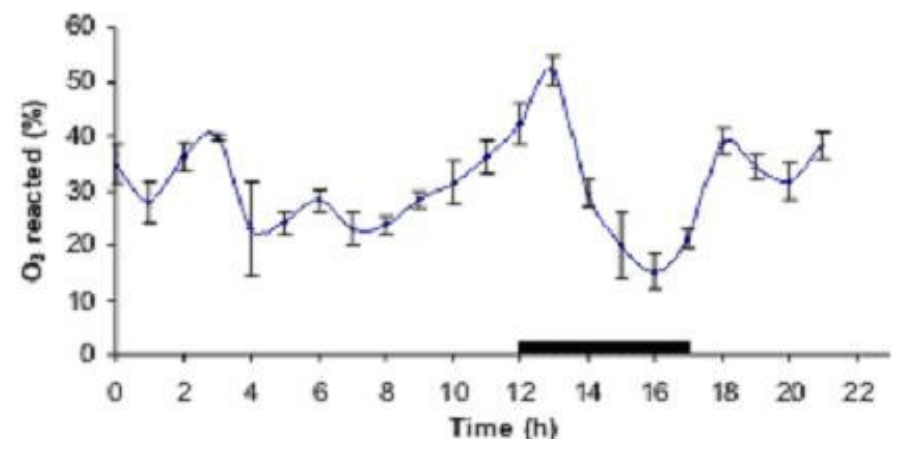

FIGURE 3. Ozone reacted (\%), 24-h profile. Vertical bars indicate \pm SE. Horizontal thick bar indicates the period of maximum values of ozone. Time is set from 0 to $23 \mathrm{~h} . \mathrm{n}=24$. 


\section{RESULTS}

\section{Ambient Ozone Concentrations}

The ambient ozone concentrations showed a typical profile, with maximum values seen at midday (40-50 $\mathrm{ppb}$ ) from 12 to $17 \mathrm{~h}$ and minimum values at night (15-20 ppb) from 3 to $7 \mathrm{~h}$.

\section{Stomatal Conductance}

Stomatal conductance $\left(\mathrm{g}_{\mathrm{s}}\right)$ was below $50 \mathrm{mmol} \mathrm{m} \mathrm{m}^{-2} \mathrm{~s}^{-1}$ at night, increasing in the morning, with a maximum at $9 \mathrm{~h}\left(333 \mathrm{mmol} \mathrm{m} \mathrm{s}^{-1}\right)$, and decreasing at midday to $150 \mathrm{mmol} \mathrm{m} \mathrm{m}^{-1}$, with a partial stomatal closure due to vapor pressure deficit (VPD) values greater than $2.5 \mathrm{kPa}$.

\section{Ozone Stomatal Fluxes}

Ozone stomatal fluxes (OSF) were calculated according to:

$$
\text { OSF }\left(n m o l m^{-2} \mathrm{~s}^{-1}\right)=\mathrm{g}_{\mathrm{s}}\left(\mathrm{O}_{3}\right)[\mathrm{O} 3] \quad \text { (Eq. 2) }
$$

where $\mathrm{g}_{\mathrm{s}}\left(\mathrm{O}_{3}\right)$ is the stomatal conductance to ozone $\left(\mathrm{mol} \mathrm{m} \mathrm{m}^{-2} \mathrm{~s}^{-1}\right)$ and $\left[\mathrm{O}_{3}\right]$ is the ambient ozone concentration $\left(\mathrm{nmol} \mathrm{mol}{ }^{-1}\right)$. Thus,

$$
\mathrm{g}_{\mathrm{s}}\left(\mathrm{O}_{3}\right)=\mathrm{g}_{\mathrm{s}} \mathrm{D}_{\mathrm{r}} \quad \text { (Eq. 3) }
$$

where $\mathrm{D}_{\mathrm{r}}=\mathrm{D}_{\mathrm{O} 3} / \mathrm{D}_{\mathrm{H} 2 \mathrm{O}}=0.613$ is the molecular diffusivity rate of ozone to water vapor[1].

\section{Biochemical Analyses}

The biochemical analyses revealed ascorbate mean levels of about $12 \mathrm{~m} M$ and dehydroascorbate levels of $0.3-1.5 \mathrm{~m} M$ in the symplasm. In the apoplast, the reduced ascorbate level was about $0.2-1 \mathrm{~m} M$ (Fig. 4), and that of dehydroascorbate was $0.11-0.77 \mathrm{~m} M$, the latter representing $35-77 \%$ of total ascorbate in the apoplast (considering hourly minimum and maximum values, respectively). The experimental $\mathrm{pH}$ values lay between 5.63 and 6.01 .

\section{Application of SODA Model}

The SODA model provided the 24-h profiles for mesophyll resistance $\left(\mathrm{r}_{\mathrm{m}}, \mathrm{s} \mathrm{m}^{-1}\right)$ (Fig. 1), ozone flux to the plasmalemma $\left(\mathrm{F}_{\mathrm{m}}, \mathrm{nmol} \mathrm{m} \mathrm{s}^{-2}\right)$ (Fig. 2), and the percentage of ozone reacting with apoplastic ascorbate $\left(\% \mathrm{O}_{3}\right.$ reacted $)$ (Fig. 3).

\section{DISCUSSION}

\section{Biochemical Analysis}

Fig. 4 shows a significant peak for ascorbate in the apoplast at $13 \mathrm{~h}$ that could be a response to the high ozone fluxes recorded between 9 and $11 \mathrm{~h}$ due to high stomatal conductances and relatively high ozone 


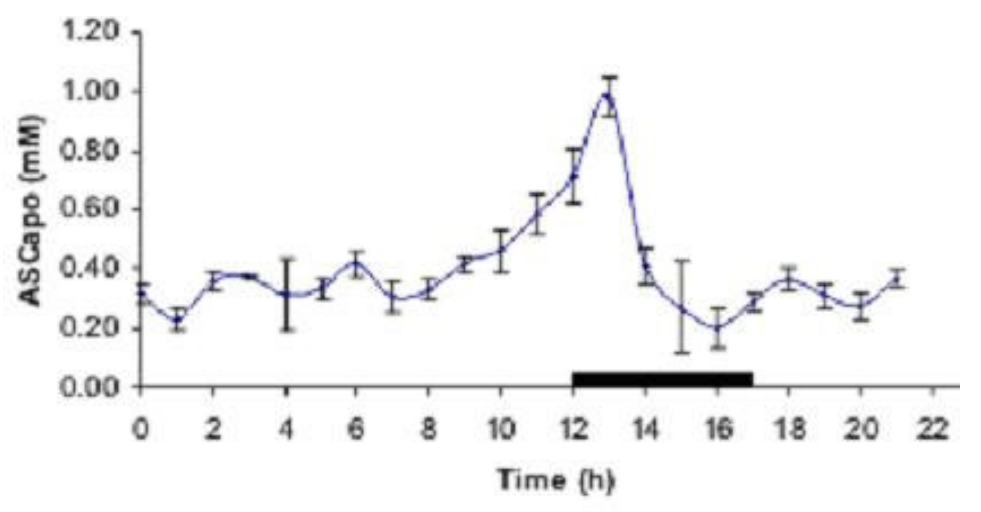

FIGURE 4. Reduced apoplastic ascorbic acid $\left(\mathrm{ASC}_{\mathrm{apo}}\right)$, 24-h profile. Vertical bars indicate \pm SE. Horizontal thick bar indicates the period of maximum values of ozone. Time is set from 0 to $23 \mathrm{~h} . \mathrm{n}=24$.

concentrations. This would be in agreement with the increasing apoplastic ascorbate levels induced by exposure to ozone described for other species[30,35]. It is also in accordance with the results of Yoshida and collaborators [43], who found that exposure to ozone in Arabidopsis increased the amount of cytosolic dehydroascorbate reductase, which is responsible for the reduction of dehydroascorbate to ascorbate.

The highest $\mathrm{pH}$ was recorded between 12-14 h, coinciding with the highest apoplastic ascorbate levels. High values of ascorbate should decrease the $\mathrm{pH}$, but in our case, the opposite was seen. Some authors have reported that the presence of ozone modifies the $\mathrm{pH}$ conditions and the delicate electrical charge equilibrium that controls the active transport of substances through the membrane[18], and this could be the reason of the increasing of the $\mathrm{pH}$ values.

\section{Application of SODA Model}

Figs. 1, 2, and 3, corresponding to the 24-h profiles for mesophyll resistance $\left(\mathrm{r}_{\mathrm{m}}, \mathrm{s} \mathrm{m}^{-1}\right)$, ozone flux to the

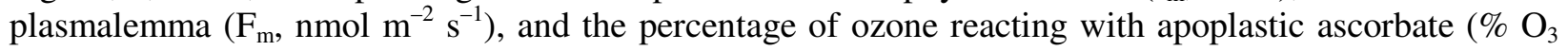
reacted), respectively, show the minimum mesophyll resistance $\left(r_{m}\right)$, a relatively low ozone flux to the plasmalemma $\left(\mathrm{F}_{\mathrm{m}}\right)$ and the maximum $\mathrm{O}_{3}$ reacted at midday $(13 \mathrm{~h})$, all coinciding with maximum apoplastic ascorbate. The ascorbate profile is consistent with the results of Chen and Gallie[5], i.e., almost constant during the early morning, with maximum values at midday, decreasing in the afternoon, and recovering by night, probably indicating that ascorbate levels are diurnally regulated. This suggests that maximum $\mathrm{O}_{3}$ reacts with maximum apoplastic ascorbate, as their maximum values coincide in time[2,34].

\section{Regression Analysis}

- Apoplastic ascorbate (AA) vs. $\mathbf{O}_{3}$ : A hemiparabolic-type relationship $\left(\mathrm{R}^{2}=0.59 ; p<0.05\right)$ was found, i.e., ascorbate seemed to increase as $\mathrm{O}_{3}$ did. When $\mathrm{O}_{3}>30 \mathrm{ppb}$ was correlated with AA levels, a better exponential regression was obtained $\left(\mathrm{R}^{2}=0.66 ; p<0.05\right.$; Fig. 5), which means that ascorbate increases, especially when high $\mathrm{O}_{3}$ concentrations occur. In other words, ascorbate seems to be directly correlated with the ozone concentration[2]. Concerning the increase in ascorbate at midday, it has already been reported that a diurnal regulation of ascorbate levels occurs that might be related to maximum daylight intensities and that may be correlated with photosynthetic activity[5]. Despite this, it is well known that maximum ozone concentrations coincide with maximum ascorbate values and, because of this, an enhanced tolerance to ozone is found[6]. 


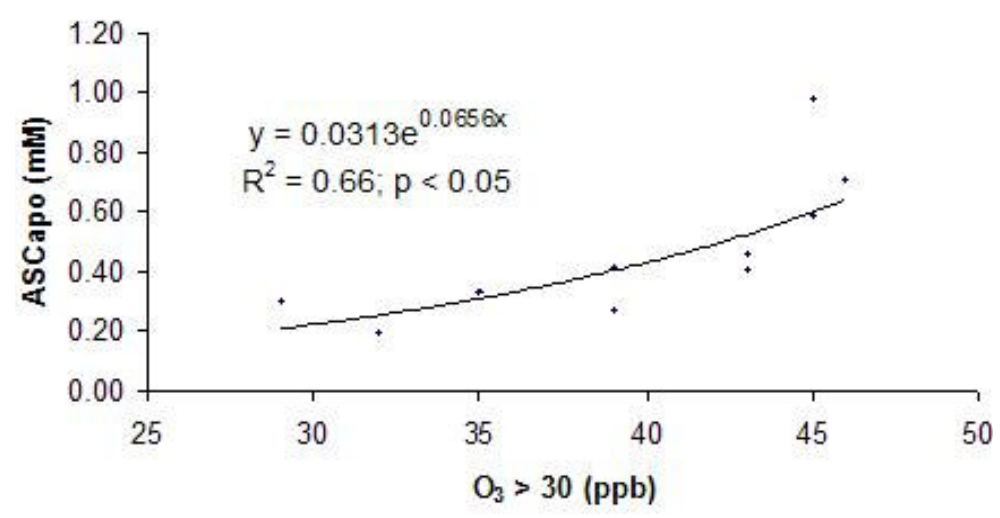

FIGURE 5. Regression for reduced apoplastic ascorbic acid (ASCapo) and ozone concentrations higher than $30 \mathrm{ppb}\left(\mathrm{O}_{3}>30 \mathrm{ppb}\right) . \mathrm{n}=10$.

- $\quad \% \mathrm{O}_{3}$ reacted vs. $\mathrm{O}_{3}$ : The same pattern as in the previous section was observed, i.e., a parabolic relationship between $\% \mathrm{O}_{3}$ reacted and $\mathrm{O}_{3}\left(\mathrm{R}^{2}=0.35 ; p<0.05\right)$; when $\mathrm{O}_{3}>30$ ppb was correlated with the $\%$ of $\mathrm{O}_{3}$ reacted, a better exponential regression was obtained $\left(\mathrm{R}^{2}=0.66 ; p<0.05\right)$, meaning that the $\%$ of $\mathrm{O}_{3}$ reacted increases considerably when high $\mathrm{O}_{3}$ concentrations occur (the $\%$ $\mathrm{O}_{3}$ reacted is directly correlated to ozone), as would be expected.

- $\% \mathrm{O}_{3}$ reacted vs. apoplastic ascorbate (AA): Based on both previous regressions, the $\% \mathrm{O}_{3}$ reacted is directly related to ascorbate, i.e., the greater the increase in ascorbate, the greater the increase in the $\%$ of $\mathrm{O}_{3}$ reacted with ascorbate[2,34]. These results are in agreement with those of Chen and Gallie[6], who found that after chronic or acute exposure to ozone, a marked reduction in ascorbate levels is seen, suggesting that ascorbate is used in the detoxification of this gas and, hence, the highest amount of ozone reacted occurs at maximum ascorbate levels. In our study, the plants were not subjected to chronic exposure to especially high ozone concentrations (14 days, ambient concentrations vs. 30 days at $100 \mathrm{ppb}$ in the Chen and Gallie study[6]), and ozone exposure at midday cannot be considered as truly acute (around 45-50 ppb vs. $200 \mathrm{ppb}$ for $2 \mathrm{~h}$ in the Chen and Gallie study[6]). Nevertheless, ascorbate was markedly reduced after midday (see Fig. 4). Two patterns were observed: one for the night hours $(\mathrm{N}$, night) and one for the day hours $(\mathrm{D}$, day). Both are very similar, and with a high amount of variance explained $\left(\mathrm{R}^{2}{ }_{-} \mathrm{N}=0.97 ; p<0.001 ; \mathrm{R}^{2}{ }_{-} \mathrm{D}=\right.$ $0.98 ; p<0.001$; Fig. 6). The main difference is the steeper slope of the night-time relationship $\left(\mathrm{m}_{\mathrm{N}}\right.$ $=76.989$ vs. $\mathrm{m}_{\mathrm{D}}=46.12$ for the day-time relationship), indicating a faster response by ascorbate to react with $\mathrm{O}_{3}$ at night, while the capacity to react with $\mathrm{O}_{3}$ during the daylight hours is greater (up to $52 \%$ ), probably because of the large pool of ascorbate.

- Ozone flux to the plasmalemma $\left(\mathbf{F}_{\mathbf{m}}\right)$ vs. stomatal conductance $\left(\mathbf{g}_{\mathrm{s}}\right)$ : This relationship is linear and direct; i.e., the greater the increase in stomatal conductance, the greater the increase in ozone flux to the mesophyll $\left(\mathrm{R}^{2}=0.72 ; p<0.05\right)$, as also expected.

- Mesophyll resistance $\left(\mathbf{r}_{\mathrm{m}}\right)$ vs. ozone $\left(\mathrm{O}_{3}>30 \mathrm{ppb}\right)$ : No clear regression for the overall ozone data was found, but a much clearer relationship was seen when $\mathrm{O}_{3}>30 \mathrm{ppb}$, with an inverse linear regression $\left(\mathrm{R}^{2}=0.71 ; p<0.01\right)$, indicating that as $\mathrm{O}_{3}$ increases, the $\underline{\mathrm{r}}_{\underline{m}}$ decreases. This is because the highest $\mathrm{O}_{3}$ concentrations are found at midday, when $\underline{\mathrm{r}}_{\underline{m}}$ is minimum, probably because of the $\% \mathrm{O}_{3}$ reacting with apoplastic ascorbate.

- Mesophyll resistance $\left(\mathbf{r}_{\mathrm{m}}\right)$ vs. apoplastic ascorbate (AA): A very marked linear and inverse regression was found $\left(\mathrm{R}^{2}=0.97-0.98 ; p<0.001\right.$; Fig. 7). Again, this is because ascorbate is maximum when mesophyll resistance is minimum and vice versa; as ascorbate increases, mesophyll resistance decreases. A dual linear regression was observed, (as in the $\% \mathrm{O}_{3}$ reacted vs. ascorbate): one for the night-time hours ( $\mathrm{N}$, night) and the other for the day-time hours ( $\mathrm{D}$, day). As before, a steeper slope was seen for the night time hours $\left(\mathrm{m}_{\mathrm{N}}=-62.89\right.$, vs. $\left.\mathrm{m}_{\mathrm{D}}=-38.072\right)$, indicating a faster 


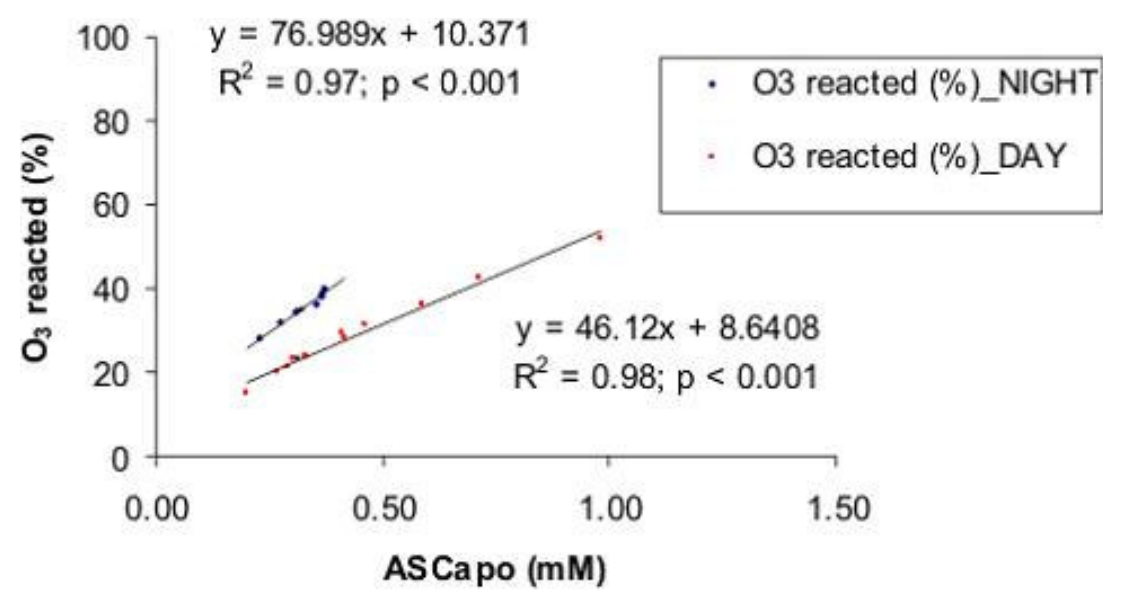

FIGURE 6. Regression for ozone reacted $\left(\mathrm{O}_{3}\right.$ reacted) and reduced apoplastic ascorbic acid $\left(\mathrm{ASC}_{\text {apo }}\right)$ for night-time (upper line, $\mathrm{O}_{3}$ reacted $(\%) \_$NIGHT; $\left.\mathrm{n}=10\right)$ and day-time hours (lower line, $\mathrm{O}_{3}$ reacted $(\%)$ DAY; $\left.\mathrm{n}=14\right)$.

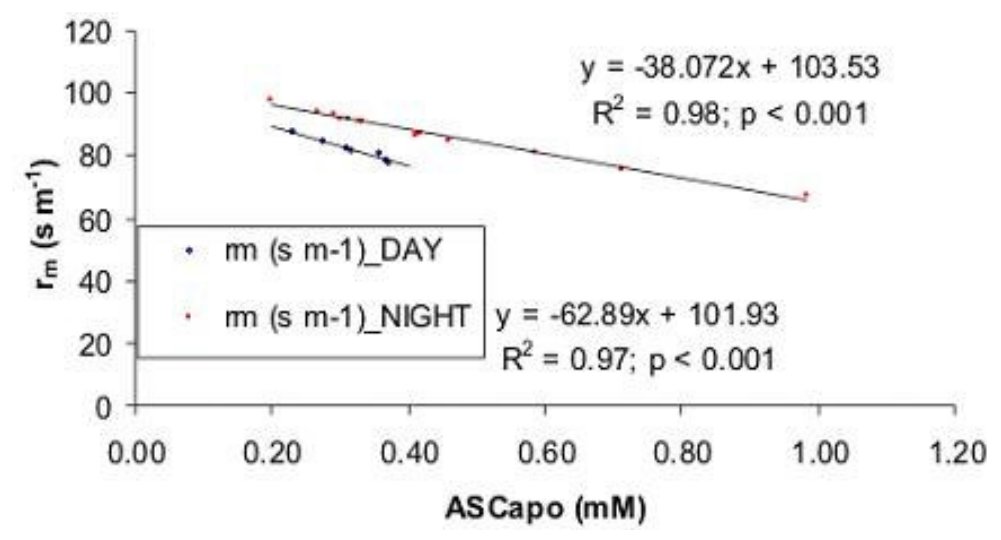

FIGURE 7. Regression for mesophyll resistance $\left(\mathrm{r}_{\mathrm{m}}\right)$ and reduced apoplastic ascorbic acid $\left(\mathrm{ASC}_{\text {apo }}\right)$ for night-time (upper line, $\mathrm{O}_{3}$ reacted $(\%) \_N I G H T ; \mathrm{n}=10$ ) and day-time hours (lower line, $\mathrm{O}_{3}$ reacted $(\%)$ DAY; $\mathrm{n}=14$ ).

decrease in mesophyll resistance at night for small increases in ascorbate, while higher ascorbate levels in the day are associated with lower decreases in $r_{m}$.

- Ozone flux to the plasmalemma $\left(\mathbf{F}_{\mathbf{m}}\right)$ vs. apoplastic ascorbate: On considering all the data together, a weak logarithmic regression was obtained $\left(\mathrm{R}^{2}=0.26 ; p\right.$ n.s. $)$, and it seems that $\mathrm{F}_{\mathrm{m}}$ tended to increase with ascorbate. However, this increase in $\mathrm{F}_{\mathrm{m}}$ is attenuated, probably due to the reaction of ascorbate with $\mathrm{O}_{3}$. Nevertheless, if only high $\mathrm{F}_{\mathrm{m}}$ values are considered $\left(\mathrm{F}_{\mathrm{m}}>0.47 \mathrm{nmol} \mathrm{m} \mathrm{s}^{-2}\right)$, corresponding to day-time values, an inverse linear regression is found $\left(\mathrm{R}^{2}=0.71 ; p<0.05\right.$; Fig. 8). This suggests that when $\mathrm{F}_{\mathrm{m}}$ increases sufficiently, ascorbate reacts with $\mathrm{O}_{3}$, decreasing the $\mathrm{F}_{\mathrm{m}}$. It is noteworthy that maximum $F_{m}$ values were observed between 7 and $9 \mathrm{~h}$, when ascorbate is still low and not very different from night-time values. As a response to such high $\mathrm{F}_{\mathrm{m}}$ values, ascorbate tended to increase during the morning and $\mathrm{F}_{\mathrm{m}}$ was reduced to intermediate values (see Figs. 2 and 4).

- Ozone flux to the plasmalemma $\left(\mathbf{F}_{m}\right)$ vs. $\% \mathbf{O}_{3}$ reacted: Exactly the same pattern was obtained as in the previous case; this is fairly logical, bearing in mind the strong direct linear regression between the percent of $\mathrm{O}_{3}$ reacted and ascorbate. In this case, the logarithmic regression was even weaker $\left(\mathrm{R}^{2}\right.$ $=0.17 ; p$ n.s. $)$ and the linear one was even stronger $\left(\mathrm{R}^{2}=0.83 ; p<0.05\right)$. 


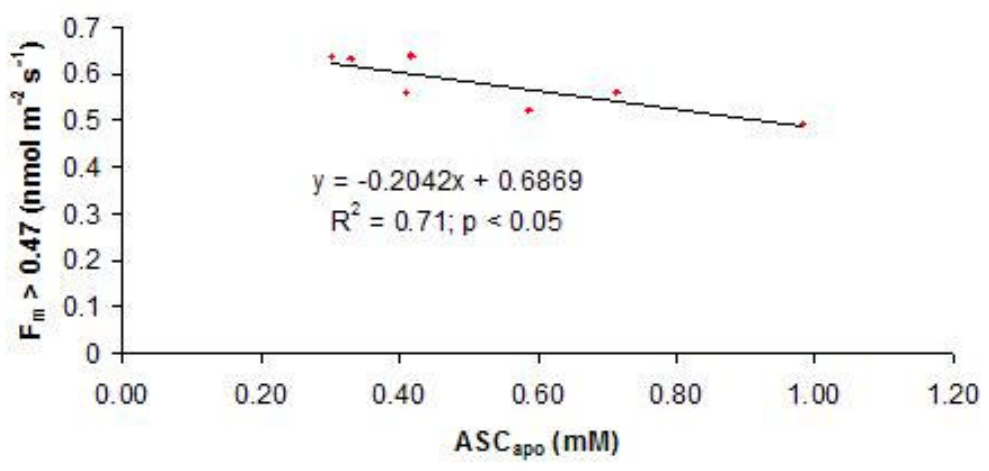

FIGURE 8. Regression for ozone flux to the plasmalemma $\left(\mathrm{F}_{\mathrm{m}}\right)$ higher than 0.47 $\mathrm{nmol} \mathrm{m} \mathrm{m}^{-2} \mathrm{~s}^{-1}$ and reduced apoplastic ascorbic acid $\left(\mathrm{ASC}_{\mathrm{apo}}\right) . \mathrm{n}=7$.

A multiple regression was obtained for apoplastic ascorbate as the dependent variable and $r_{m}, F_{m}$, and the $\% \mathrm{O}_{3}$ reacted as independent variables. The result was a very strong correlation $\left(\mathrm{R}^{2}=0.99 ; p=\right.$ $0.00046)$, i.e., those three parameters were able to explain almost $100 \%$ of the variance in apoplastic ascorbate.

\section{CONCLUSIONS}

The computer model used in this experiment, SODA, has been shown to afford accurate results and is able to simulate a realistic ozone detoxification in the apoplast by ascorbate for a Mediterranean wheat cultivar (Triticum durum Desf. Cv. Camacho). Degrees of ozone detoxifications up to $52 \%$ were found at midday, when maximum ozone concentrations and maximum apoplastic ascorbate were present. Apoplastic ascorbate highest levels seem to coincide with the highest ambient ozone concentrations and, hence, with the percentage of ozone reacted, especially during the day, when a higher detoxification capacity was observed. Mesophyll resistance was minimum at this time and the ozone flux to the plasmalemma was reduced because of ozone depletion by apoplastic ascorbate. The regression analysis of apoplastic ascorbate vs. ozone showed a good correlation, and as a consequence of that, the regression analysis of apoplastic ascorbate vs. percent of ozone detoxification was also very good, because apoplastic ascorbate and ozone maximum values coincide in time and apoplastic ascorbate has been demonstrated to be an excellent antioxidant against ozone. To amplify that matter, it would have been desirable to compare the daily cycle of apoplastic ascorbate of the plants studied with the ascorbate cycle for plants not subjected to ozone exposure, thus enabling speculation about which factors would be responsible for the increases and decreases in ascorbate levels, since ozone is not in fact the only factor that affects the ascorbate cycle. Nevertheless, this was not the aim of our study; instead, we wished to check the effectiveness and accuracy of the SODA model applied to a Mediterranean wheat cultivar. The SODA model results indicated that apoplastic ascorbate reacts with ozone, ascorbate being one of the main antioxidants that protect plants, as it has been already and largely cited in the scientific literature.

\section{ACKNOWLEDGMENTS}

Thanks are given to Dr. Agueda González Rodriguez (IMIDRA) for her intermediation with her research institute in order to be able to make the experimental measurements at El Encin. 


\section{REFERENCES}

1. Baldocchi, D.D., Hicks, B.B., and Camera, P. (1987) A canopy stomatal resistance model for gaseous deposition to vegetated surfaces. Atmos. Environ. 21(1), 91-101.

2. Barnes, J.D., Zheng, Y., and Lyons, T. (2002) Plant resistance to ozone: the role of ascorbate. In Air Pollution and Biotechnology: Prospects for Phytomonitoring and Phytoremedation. Omasa, K., Saji, H., Youssefian, S., and Kondo, N., Eds. Springer-Verlag, Tokyo. pp. 235-252.

3. Chameides, W.L. (1989) The chemistry of ozone deposition to plant leaves: role of ascorbic acid. Environ. Sci. Technol. 23, 595-600.

4. Chappelka, A.H. and Samuelson, L.J. (1998) Ambient ozone effects on forest trees of the eastern United States: a review. New Phytol. 139, 91-108.

5. Chen, Z. and Gallie, D.R. (2004) The ascorbic acid redox state controls guard cell signaling and stomatal movement. Plant Cell 16, 1143-1162.

6. Chen, Z. and Gallie, D.R. (2005) Increasing tolerance to ozone by elevating foliar ascorbic confers greater protection against ozone than increasing avoidance. Plant Physiol. 138, 1673-1689.

7. Cieslik, S.A. (2004) Ozone uptake by various surface types: a comparison between dose and exposure. Atmos. Environ. 38, 2409-2420.

8. Danielsson, H., Karlsson, G.P., Karlsson, P.E., and Pleijel, H. (2003) Ozone uptake modelling and flux-response relationships - an assessment of ozone-induced yield loss in spring wheat. Atmos. Environ. 37, 475-485.

9. Davison, A.W. and Barnes, J.D. (1998) Effects of ozone on wild plants. New Phytol. 139, 135-151.

10. Emberson, L.D., Ashmore, M.R., Cambridge, H.M., Simpson, D., and Tuovinen, J.-P. (2000) Modelling stomatal ozone flux across Europe. Environ. Pollut. 109, 403-413.

11. Erisman, J.W. and Van Pul, A. (1994) Parameterization of surface resistance for the quantification of atmospheric deposition of acidifying pollutants and ozone. Atmos. Environ. 28(16), 2595-2607.

12. Fowler, D., Flechard, C., Cape, J.N., Storeton-West, R.L., and Coyle, M. (2001) Measurements of ozone deposition to vegetation quantifying the flux, the stomatal and non-stomatal components. Water Air Soil Pollut. 130, 63-74.

13. Fuhrer, J. (2000) Introduction to the special issue on ozone risk analysis for vegetation in Europe. Environ. Pollut. 109, 359-360.

14. Fuhrer, J. and Booker, F. (2003) Ecological issues related to ozone: agricultural issues. Environ. Int. 29, $141-154$.

15. Fumagalli, I., Gimeno, B.S., Velissariou, D., De Temmerman, L., and Mills, G. (2001) Evidence of ozone-induced adverse effects on crops in the Mediterranean region. Atmos. Environ. 35, 2583-2587.

16. Grünhage, L., Krause, G.H.M., Köllner, B., Bender, J., Weigel, H.-J., Jäger, H.-J., and Guderian, R. (2001) A new flux-orientated concept to derive critical levels for ozone to protect vegetation. Environ. Pollut. 109, 373-392.

Halliwell, B. and Gutteridge, J.M.C. (1989) Free Radicals in Biology and Medicine. Clarendon, Oxford.

Heath, R.L. (1987) The biochemistry of ozone attack on the plasma membrane of plant cell. Rec. Adv. Phytochem. 21, 29-54.

Heath, R.L. (1994) Possible mechanisms for the inhibition of photosynthesis by ozone. Photosynth. Res. 39, 439-451.

Kanofsky, J.R. and Sima, P.D. (1995) Reactive absorption of ozone by aqueous biomolecule solutions: implications for the role of sulfhydryl compounds as targets for ozone. Arch. Biochem. Biophys. 316, 52-62.

21. Kollist, H., Moldau, H., Oksanen, E., and Vapaavuori, E. (2001) Ascorbate transport from the apoplast to the symplast in intact leaves. Physiol. Plant. 113(3), 377-383.

22. Kornberg, A. and Horecker, B.L. (1955) Glucose-6-phosphate dehydrogenase. In Methods in Enzymology. Vol. 1. Colowick, S.P. and Kaplan, N.O., Eds. Academic Press, New York. pp. 323-325.

23. Lee, E.H. (1991) Plant resistance mechanisms to air pollutants: rhythms in ascorbic acid production during growth under ozone stress. Cronobiol. Int. 8, 93-102.

24. Luwe, M., Takahama, U., and Heber, U. (1993) Role of ascorbate in detoxifying ozone in the apoplast of spinach (Spinacea oleracea L.) leaves. Plant Physiol. 101, 969-976.

25. Lyons, T., Plöchl, M., Turcsányi, E., and Barnes, J.D. (1999a) Extracellular antioxidants: a protective screen against ozone?. In Environmental Pollution and Plant Responses. Agrawal, S. and Agrawal, M., Eds. CRC Press/Lewis Publishers. Boca Raton, FL. pp. 183-201.

26. Lyons, T., Ollerenshaw, J.H., and Barnes, J.D. (1999b) Impacts of ozone on Plantago major L.: apoplastic and symplastic antioxidant status. New Phytol. 141, 253-263.

27. Mehlhorn, H., Tabner, B.J., and Wellburn, A.R. (1990) Electron spin resonance evidence for the formation of free radicals in plants exposed to ozone. Physiol. Plant. 79, 377-383.

28. Moldau, H. and Bichele, I. (2002) Plasmalemma protection by the apoplast as assessed from above-zero ozone concentrations in leaf intercellular air spaces. Planta 214, 484-487.

29. Nobel, P.S. (1991) Physicochemical and Environmental Plant Physiology. Academic Press, San Diego.

30. Padu, E., Moldau, H., and Bichele, I. (1996) Activation of antioxidative system peroxidase-ascorbate in cell-walls of Phaseolus vulgaris L. leaves under acute ozone exposure. In Plant Peroxidases: Biochemistry and Physiology. 
Obinger, C., Burner, U., Ebermann, R., Penel, C., and Greppin, H., Eds. Proceedings IV International Symposium Rochat-Bauman, University of Geneva. pp. 363-368.

31. Pell, E.J., Schlagnhaufer, C.D., and Arteca, R.N. (1997) Ozone-induced oxidative stress: mechanisms of action and reaction. Physiol. Plant. 100, 264-273.

32. Pleijel, H., Danielsson, H., Ojanperä, K., De Temmerman, L., Högy, P., Badiani, M., and Karlsson, P.E. (2004) Relationships between ozone exposure and yield loss in European wheat and potato - a comparison of concentration and flux-based exposure indices. Atmos. Environ. 38, 2259-2269.

33. Plöchl, M. (1992) The Importance of Apoplastic Acid in the Scavenging of Ozone and Nitrogen Dioxide in Plant Leaves: the Dynamic Modelling of the Involvement of Metabolic Process in the Leaf System [Ph.D. thesis]. Johann Wolfgang Goethe-University, Frankfurt, Germany.

34. Plöchl, M., Lyons, T., Ollerenshaw, J., and Barnes, J.D. (2000) Simulating ozone detoxification in the leaf apoplast through the direct reaction with ascorbate. Planta 210, 454-467.

35. Ranieri, A., D’urso, G., Nali, C., Lorenzini, G., and Soldatini, G.F. (1996) Ozone stimulates apoplastic antioxidant systems in pumpkin leaves. Physiol. Plant. 97, 381-387.

36. Reich, P.B. (1987) Quantifying plant response to ozone: a unifying theory. Tree Physiol. 3, 63-91.

37. Takahama, U. and Oniki, T. (1992) Regulation of peroxidase-dependant oxidation of phenolics in the apoplast of spinach leaves by ascorbate. Plant Cell Physiol. 33, 379-387.

38. Tuovinen, J.P. (2000) Assessing vegetation exposure to ozone: properties of AOT40 index and modifications of deposition modelling. Environ. Pollut. 109, 361-372.

39. Turcsányi, E., Lyons, T., Plöchl, M., and Barnes, J.D. (2000) Does ascorbate in the mesophyll cell walls form the first line of defense against ozone? 1. Testing the concept using broad bean (Vicia faba L.) J. Exp. Bot. 51, 901-910.

40. UN/ECE (2001) Mapping critical levels for vegetation. In Manual on Methodologies and Criteria for Mapping Critical Levels/Loads and Areas where they are Exceeded. Gregor, H.-D., Werner, B., and Spranger, T., Eds. Federal Environmental Agency. Umweltbundesamt, Berlin. pp. 45-48. ISSN 0722-186X.

41. UN/ECE (2004) Mapping critical levels for vegetation. In Manual on Methodologies and Criteria for Modelling and Mapping Critical Loads and Levels and Air Pollution Effects, Risks and Trends. Gregor, H.-D., Werner, B., and Spranger, T., Eds. Federal Environmental Agency. Umweltbundesamt,Berlin,Germany. http://www.icpmapping.org; http://icpvegetation.ceh.ac.uk

42. Van der Vliet, A., O’Neill, C.A., Eiserich, J.P., and Cross, C.E. (1995) Oxidative damage to extracellular fluids by ozone and possible protective effects of thiols. Arch. Biochem. Biophys 321, 43-50.

43. Yoshida, S., Tamaoki, M., Shikano, T., Nakajima, N., Ogawa, D., Ioki, M., Aono, M., Kubo, A., Kamada, H., Inoue, Y., and Saji, H. (2006) Cytosolic dehydroascorbate reductase is important for ozone tolerance in Arabidopsis thaliana. Plant Cell Physiol. 47(2), 304-308.

44. Yu, Q., Tang, C., and Kuo, J. (2000) A critical review on methods to measure apoplastic pH in plants. Plant Soil 219, 29-40.

45. Zheng, Y., Lyons, T., Ollerenshaw, J.H., and Barnes, J.D. (2000) Ascorbate in the leaf apoplast is a factor mediating ozone resistance in Plantago major L. Plant Physiol. Biochem. 38(5), 403-411.

\section{This article should be cited as follows:}

De la Torre, D. (2008) Quantification of mesophyll resistance and apoplastic ascorbic acid as an antioxidant for tropospheric ozone in durum wheat (Triticum durum Desf. cv. Camacho). TheScientificWorldJOURNAL 8, 1197-1209. DOI 10.1100/tsw.2008.149. 

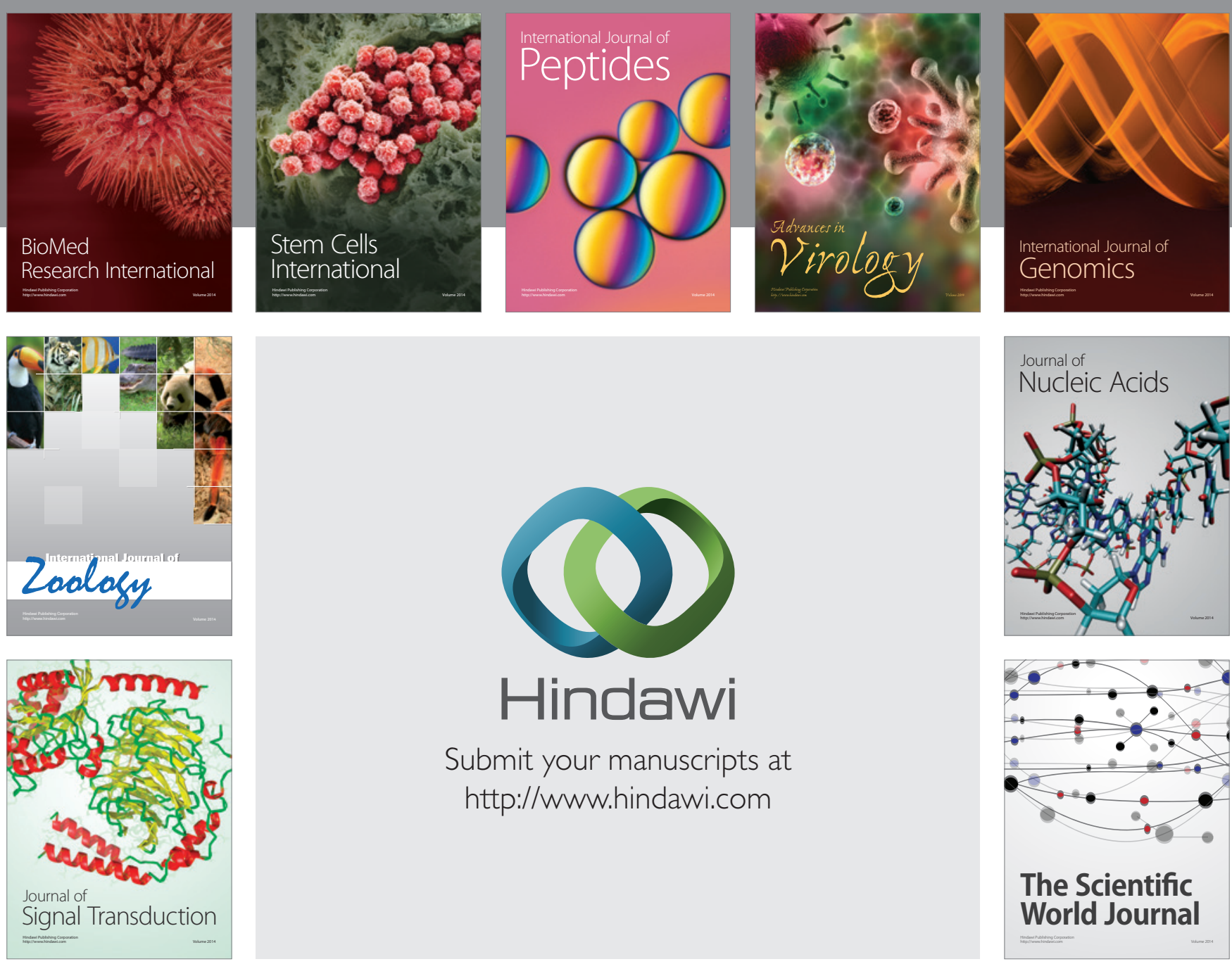

Submit your manuscripts at

http://www.hindawi.com
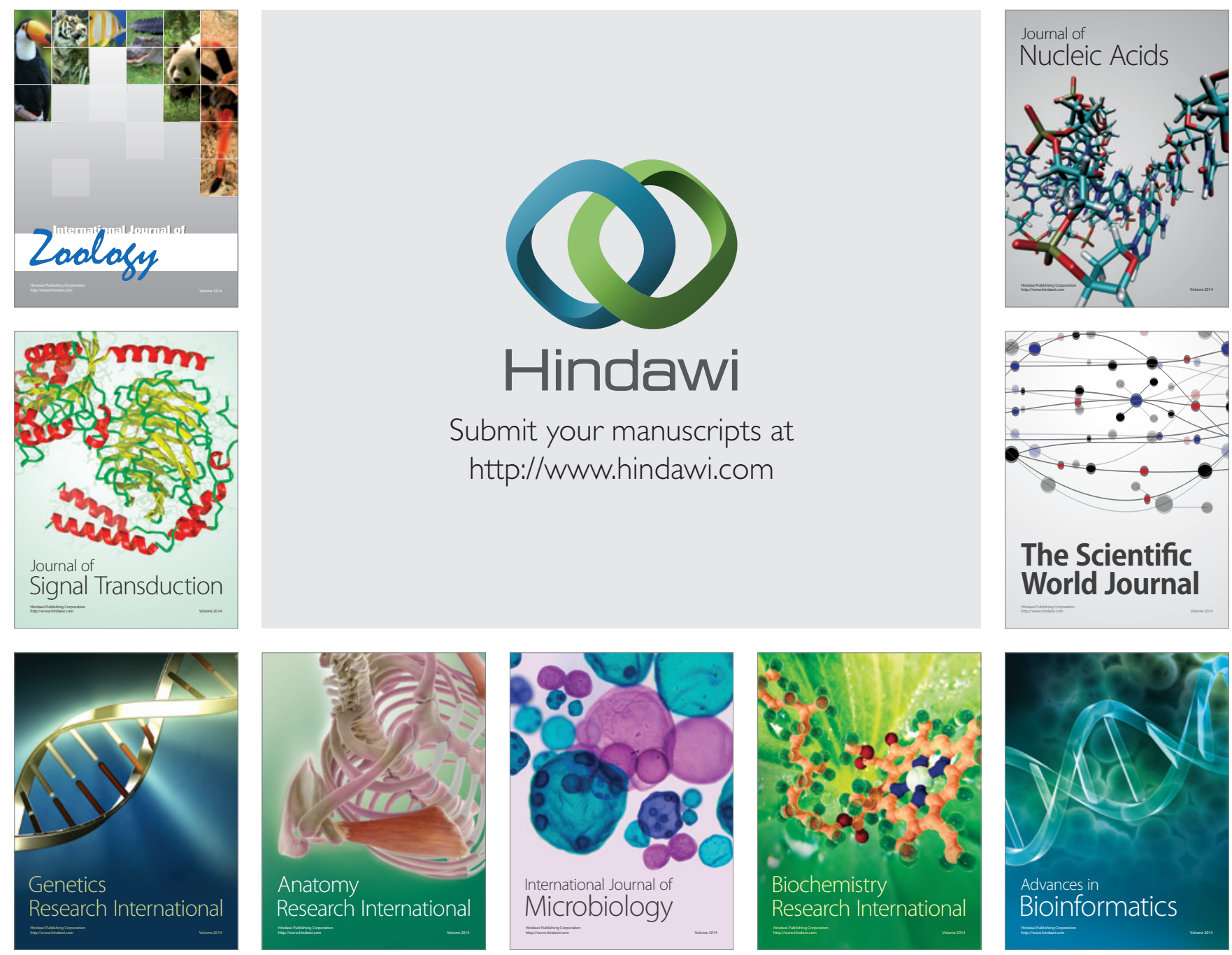

The Scientific World Journal
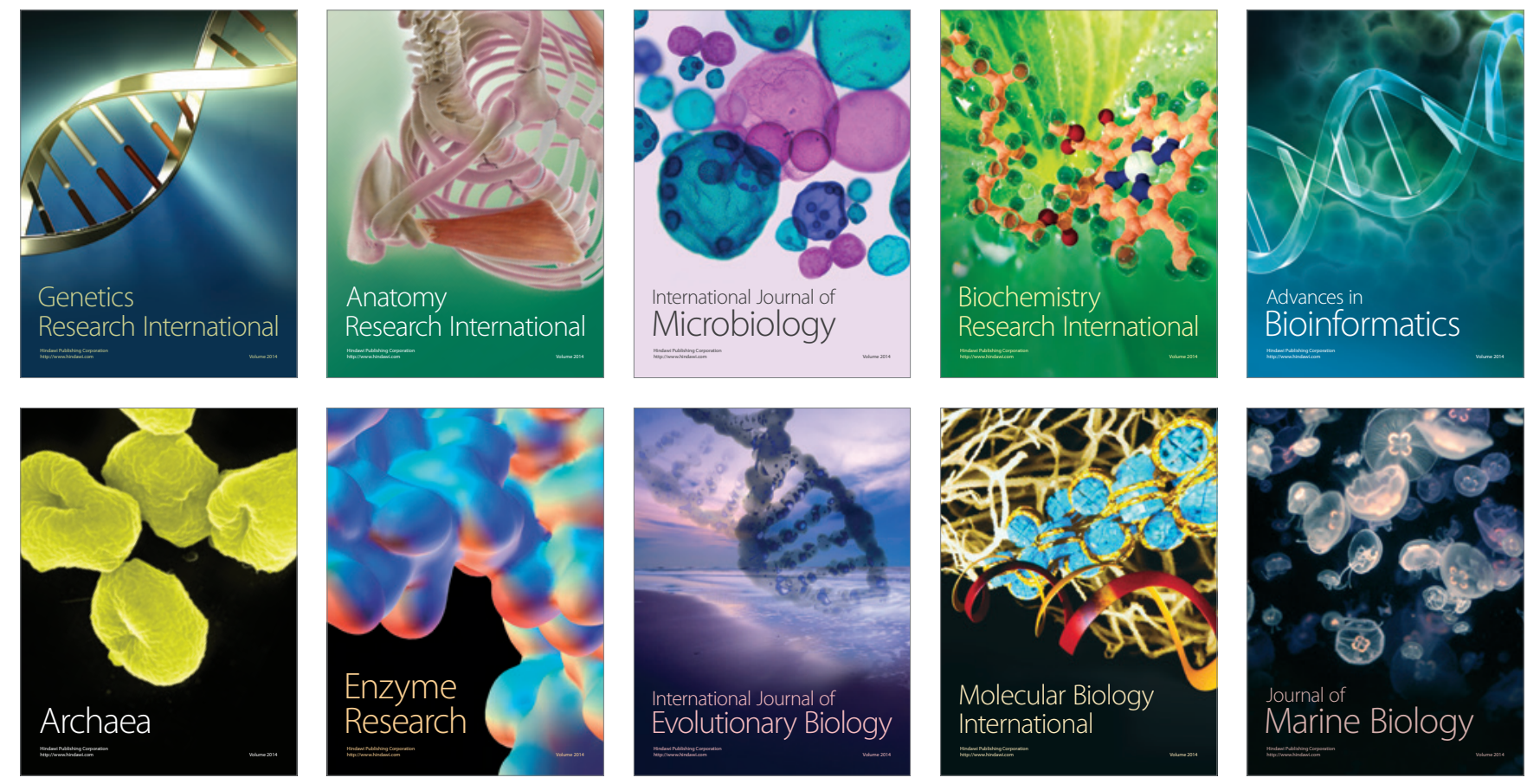